\title{
ANALISIS RELASI TEKNOLOGI, INSTITUSI DAN AGENSI DALAM TRANSFORMASI PELAYANAN PUBLIK DI JAKARTA
}

\author{
Ely Yani \\ Departemen Sosiologi Universitas Indonesia \\ Yaniely4@gmail.com
}

\begin{abstract}
This study focuses on the effort of public services through technology adoption. One of forms is the responsibility report Rukun Tetangga in Jakarta through the Qlueapplication The implementation of Qlue is how it links between technology, institution, and agency. The author tries to review the process of relation among these three aspects occur to promote the transformation of public services in Jakarta through adoption of Qlue technology for accountability report in RT. The main argument on this article is that the process of relation technology, institution, and agency as they become the main factors in transformation of public services. This article attempts to give different perspective as the other articles with same themes only show the role of the advanced technology in public services. Via the depth interview and observation method in the place that become the sample is in one of the regions which using Qlue in its best way is KelurahanGalur, Central Jakarta. The conclusion, transformation through technology can occur when technology can be well institutionalized through rules. However, institutions must also be able to take into account the relationship between agents and the institutional environment.
\end{abstract}

\begin{abstract}
Abstrak
Studi ini berfokus pada upaya transformasi pelayanan publik melalui adopsi teknologi. Salah satu bentuknya adalah laporan pertanggung jawaban RT di Jakarta melalui aplikasi Qlue. Implementasi Qlue merupakan kaitan antara teknologi, institusi dan agensi. Penulis mencoba mengkaji mengenai bagaimana proses relasi antara teknologi, institusi, dan agensi dalam mendorong transformasi pelayanan publik di Jakarta melalui pengadopsian teknologi Qlue pada laporan pertanggung jawaban RT. Argumen utama dalam artikel ini adalah proses relasi antara teknologi, institusi dan agensi merupakan faktor yang sangat berperan dalam transformasi pelayanan publik. Artikel ini mencoba mengisi pandangan dari artikel sebelumnya yang hanya memperlihatkan peranan perubahan teknologi dalam transformasi pelayanan publik. Melalui pendekatankualitatifdenganwawancara mendalam dan observasi di salah satu wilayah penanganan Qlue terbaik yaitu kelurahan Galur, Jakarta Pusat. Kesimpulanartikelini transformasi melalui teknologi dapat terjadi ketika teknologi dapat terinstitusionalisasi dengan baik melalui aturan.Namun, institusi juga harus dapat memperhitungkan hubungan antara agen dan lingkungan institusional
\end{abstract}

Keywords: Transformation, Public Services, Institutionalization. 


\section{PENDAHULUAN}

Pelayanan publik yang transparan dan akuntabel merupakan kewajiban negara dalam memenuhi kebutuhan warga negaranya. Hal ini tertuang dalam UndangUndang No. 25 Tahun 2009 yang menyatakan bahwa negara berkewajiban membangun kepercayaan masyarakat atas pelayanan publik yang dilakukan oleh penyelenggara pelayanan publik. Hal ini berbeda dengan pandangan Styawan (2013) bahwa pelayanan publik yang ada di Indonesia masih penuh dengan ketidakpastian waktu, biaya, dan prosedur pelayanannya. Permasalahan ini merupakan permasalahan terbesar yang dirasakan oleh masyarakat Jakarta (Detik. com 2016). Data mengenai pelayanan publik memperlihatkan bahwa Provinsi DKI Jakarta termasuk kedalam Provinsi dengan tingkat akuntabilitas dan transparansi pada pelayanan publik yang rendah dengan menduduki peringkat ke 16 dari 33 provinsi (Ombudsman 2015).

Beberapa waktu saat ini, Pemerintah provinsi DKI Jakarta melakukan berbagai upaya untuk meningkatkan akuntabilitas dan transparansi pelayanan publik dalam membangun kepercayaan masyarakat. Salah satu bentuk transformasi pelayanan publik di Jakarta adalah dengan mengadopsi teknologi informasi dalamlaporan pertanggungjawaban RT. Sebelumnya, RT melakukan laporan pertanggungjawaban melalui laporan berbasis kertas namun, dalam transformasi pelayanan publik ini, laporan pertanggungjawaban RT diakomodir di dalam suatu aplikasi yang dapat diunduh masyarakat secara keseluruhan sehingga laporan kegiatan RT dapat dilihat oleh seluruh masyarakat.

Dalam melihat fenomena transformasi pelayanan publik ini, Penulis merujuk dari beberapa penelitian yang mengungkapkan mengenai keberhasilan suatu negara dalam transformasi pelayanan publik. Studi Mahler (2010) dan Brewer (2007) di USA misalnya, memperlihatkan dukungan negara Amerika dalam sistem pelayanan. Hal ini dimulai dari pemerintah manual menjadi e-governance yang menciptakan kemudahan dalam pelayanan publik. Negara memiliki pandangan bahwa masyarakat adalah konsumen sehingga dengan membentuk New Public Management (NPM) Maka pelayanan publik dapat lebih maksimal (Mahler 2010; Brewer 2007). E-governance meningkatkan trust pada pemerintah dan meningkatkan partisipasi masyarakat (Cailer 2016). Bahkan menurut Smith (2010) e-governance dalam sektor publik di Australia meningkatkan partisipasi masyarakat dalam pelaporan pengaduan masyarakat.

Adopsi teknologi juga berperan dalam mewujudkan pelayanan publik melalui smart city. Salah satu kota di Australia yang menggunakan smart city adalah Brisbane. Teknologi dalam smart city membuat selururh informasi mengenai Brisbane dalamourbrsibane.com dapat di akses publik baik yang bertujuan untuk meningkatkan pelayanan, dan membangun relasi sosial. Sekitar 8o persen transaksi pihak council dapat dipantau oleh masyarakat yang menghasilkan kepercayaan dan partisipasi masyarakat dan membangun kepercayaan investor untuk melakukan bisnis di Brisbane (Odendaalan 2003). Dalam kasus singapura, menurut Mahizhnan (1999) penggunaan teknologi pada institusi pemerintah telah berhasil dalam membangun singapura menjadi intelligent island melalui private sector. Implementasi smart city di salah satu kota Kitatkyusu Jepang mengalami kesuksesan melalui adopsi teknologi (Chafield dan Redrick 2015). Pada kasus Italia, adopsi teknologi dalam smart city dapat menciptakan sinergi antara pemerintah, masyarakat, civil society, firma, organisasi non profit (Dameri et al 2015).

Penulis membandingkan dengan studi lainnya mengenai kegagalan transformasi pelayanan publik. Salah satunya adalah modifikasi sistem di perlihatkan pada penelitian yang dilakukan oleh Utomo (2008) mengenai pengaduan layanan masyarakat di Semarang, pengaduan yang selama ini ditujukan langsung ke pemerintah provinsi Semarang kemudian diubah bentuknya kedalaminsititusibaruyangdapatmenjadikan sistem pengaduan lebih terintegrasi yaitu 
Pusat Penanganan Pengaduan Pelayanan Publik ( $\left.\mathrm{P}_{5}\right) . \mathrm{P}_{5}$ ini bertugas untuk membantu walikota Semarang dalam mengkordinasi, melaksanakan, dan menangani pengaduan masyarakat. Wadah pelaporan ini belum dapat membuat masyarakat aktif dalam pelaporan dikarenakan sistem yang diadopsi masih menggunakan sistem lama hanya dengan menggabungkan institusi ke dalam satu pusat integrasi saja dengan sosialisasi yang rendah maka masyarakat masih banyak belum mengetahui program ini. Dalam negara berkembang lainya seperti India, smart city tidak berjalan baik karena infrastruktur teknologi informasi yang masih buruk sehingga terjadi permasalahan dalam pengadopsian teknologi dan performa organisasi publik yang mengadopsi smart city (Sumanjeet, 2006)

Berdasarkan studi-studi diatas, penulis setuju bahwa perlunya mediasi teknologi dalam transformasi sistem pelayanan publik terutama yang diperlihatkan smart city namun artikel diatas hanya memperlihatkan peran teknologi yang berdampak pada keberhasilan pemerintah dalam transformasi pelayanan publik. Menurut penulis, proses relasi antara teknologi, institusi dan agensi memiliki peran besar dalam perubahan yang terjadi pada pelayanan publik. Maka dari itu, dalam kasus implementasi aplikasi Qlue bagi RT di Kelurahan Galur. Penulis berargumen bahwa Qlue sebagai teknologi sangat berkaitan dengan peraturan-peraturan dan sistem yang dibuat oleh Pemerintah Provinsi DKI Jakarta sebagai Institusi dan aparat pemerintah seperti kelurahan dan RT sebagai Agensi sehingga proses antara ketiga hal tersebut lah yang berperan dalam upaya transformasi pelayanan publik.

\section{METODE}

Penelitian ini dilakukan dengan pendekatan penelitian kualitatif dan menggunakan metode studi kasus untuk menggali informasi secara lebih mendalam untuk mendapatkan informasi mengenai bagaimana proses relasi antara teknologi, institusi, dan agensi dalam mendorong transformasi pelayanan publik di Jakarta melalui pengadopsian teknologi Qlue pada laporan pertanggung jawaban RT(Creswell 2007). Pengumpulan data dalam penelitian ini berdasarkan pada data primer dan data sekunder. Data primer yang di dapatkan melalui wawancara mendalam dan observasi pada Kelurahan Galur. Data sekunder di dapatkan melalui pihak Jakarta Smart City. Informan dalam penelitian ini berjumlah sepuluh orang dengan teknik purposive samplingberdasarkan subjek yang menguasai permasalahan mengenai sistem Qlue, dan bersedia untuk memberikan informasi mengenai sistem Qlue bagi RT yaitu dua orang RT, Lurah Galur, Kepala Sarana dan Prasarana Galur, Kordinator Qlue Galur, Pemerintah Provinsi DKI Jakarta melalui Jakarta Smart City, Pengembang sistem Qlue, dan dua orang masyarakat pengguna Qlue. Tempat penelitian dilakukan di Kelurahan Galur, Kecamatan Johar baru, Jakarta, Indonesia. Pemilihan tempat ini berdasarkan ranking kelurahan terbaik dalam penangan Qlue pada saat penelitian ini dilakukan.

\section{HASIL DAN PEMBAHASAN}

\section{Hubungan Institusi dan Agensi dalam Adopsi Teknologi}

Dalam buku Sosiologi Korupsi: Isu, Konsep, dan Perdebatan mengenai Institusionalisme terdapat pemikiran bahwa hubungan lingkungan sosial berupa struktur dan norma memiliki keterkaitan dengan individu dan organisasi. Hal ini dapat terjadi karena dipengaruhi oleh lima dimensi yaitu pertama, pembahasan yang tidak hanya pada individu namun terletak juga pada organisasi. Kedua, otonomi juga dapat mempengaruhi institusi dan yang ketiga adalah aktor rasional melihat institusi sebagai bentuk struktur yang membatasi tindakan. Dimensi keempat, terjadi dinamika internal dalam organisasi pada tahap menanggapi lingkungan institusional. Kelima, keragaman institusionaldapatmempengaruhiorganisasi. Meutia Rochman \& Rochman Ahwan (2014: 46 ). Media insititusional sangat berpengaruh dalam membentuk organisasi dan interkasi 
Tabel 1. Tiga Pilar Institusi

\begin{tabular}{|l|l|l|l|}
\hline & Regulatif & Normatif & Kognitif Kultural \\
\hline Dasar Kepatuhan & Kegunaan & Kewajiban Sosial & $\begin{array}{l}\text { Sudah biasa } \\
\text { pemahaman } \\
\text { bersama }\end{array}$ \\
\hline Dasar Tatanan & Regulatif Rules & Harapan mengikat & $\begin{array}{l}\text { Skema konstitutif } \\
\text { Mimetik }\end{array}$ \\
\hline Mekanisme & Paksaan & Normatif & Ortodoksi \\
\hline Logika & Instrumentalitas & Kewajaran & $\begin{array}{l}\text { Kepercayaan } \\
\text { bersama }\end{array}$ \\
\hline Indikator & $\begin{array}{l}\text { Aturan, Undang- } \\
\text { undang, Sanksi }\end{array}$ & $\begin{array}{l}\text { Sertifikat } \\
\text { Akreditasi }\end{array}$ & $\begin{array}{l}\text { Logika Aksi } \\
\text { bersama }\end{array}$ \\
\hline Perasaan & Takut bersalah & Malu/kehormatan & $\begin{array}{l}\text { Kepastian/ } \\
\text { kebingungan }\end{array}$ \\
\hline Basis Legitimasi & Sanksi Legal & $\begin{array}{l}\text { Dikelola secara } \\
\text { moral }\end{array}$ & $\begin{array}{l}\text { Dipahami diakui } \\
\text { secara kultural }\end{array}$ \\
\hline
\end{tabular}

Sumber: Meutia Rochman \& Rochman Ahwan (2014, 46)

pada tingkat mikro. Interaksi ini dilihat sebagai media pertukaran simbolik yang merupakan gabungan dari sistem kultural, ideologi, meta- ideologi dan norma. (GanieRochman, 2014)

Institusi juga mengandung elemen intergrasi antara regulasi dan norma yang kemudian menjadi dasar dalam pemberian arahan pada aktor. Terdapat tiga pilar institusi yang membangun teori tersebut yaitu terdiri dari elemen regulatif, elemen normatif dan elemen kognitif kultural. Elemen regulatif terdiri dari penetapan aturan main, pemantauan dan pemberian sanksi baik secara formal maupun informal. Elemen normatif meliputi nilai dan norma yang dimaksud nilai di sini adalah yang menetapkan mana yang diinginkan dan dianggap baik termasuk konstruksi tentang standar. Norma adalah rumusan bagaimana sesuatu harus dilakukan, tujuannya dan cara apa untuk mencapainya. Terdapat nilai dan norma yang berlaku secara umum dan ada pula yang berlaku untuk kelompok tertentu. Elemen kultural kognitif lebih menekankan pentingnya kerangka pemberian makna dari para aktor. Meutia Rochman \& Rochman Ahwan (2014, 46-47). Penjelasan secara tabel akan membantu dalam memahami teori ini.

Namun, institusi tidak selamanya berkuasa atas aktor rasional, di dalam ranah institusi terdapat perhitungan hubungan antara agen dan lingkungan institusional. Tindakan manusia dan institusi saling melekat. Pandangan ini melihat pengaruh institusi dalam tindakan dan gagasan para aktor. Namun, para aktor ini melakukan pertimbangan atas kesempatan dan hambatan yang disediakan institusi. Hal ini dikemukakan oleh Lawrence et al (2009) dalam bagan di bawahyangakan menjelaskan hubungan antara institusi dan aksi agensi.

Fokusstudiiniadalahbagaimanaefekdari aksi para aktor di dalamnya untuk melakukan transformasi dalam peraturan institusional (Lawrence et al, 2009). Institusi menyediakan template tindakan serta mekanisme regulatif yang akan menegakkan template tersebutdan tindakan agen akan mempengaruhi template dan mekanisme regulatif tersebut. Lawrence et al (2009) tidak pernah menolak pengaruh institusi pada tindakan namun perspektif ini ingin memberikan pandangan lain bahwa tindakan aktor juga mempengaruhi institusi. Terdapat 3 elemen dalam mendeskripsikan mengenai peran agen yang berdampak pada institusi. Pertama, pandangan ini menyoroti keterampilan kesadaran dan refleksivitas aktor dan kolektif individual. Kedua, institusi dibentuk sebagai tindakan dari kesadaran aktor kolektif. Ketiga, tindakan sebagai praktek yang ditujukan untuk mengubah tatanan institusi dalam aturan kelembagaan. 
Dalam pandangan Yang (2003), neoinstitutionalismedapatmembahasperubahan institusional yang termasuk dalam beberapa perubahan adopsi teknologi. Le Porte et al (2002) menggunakan neo-institutionalisme dalam melihat fenomena birokrasi yang mengadopsi teknologi web sebagai bagian dari institutional isomorphism. hal ini karena sebagai sebuah institusi, terdapat mekanisme untuk bertahan atau survive yang kemudian dilakukan dengan cara difusi norma dan regulasi dan juga melakukan adopsi (Yang 2003; Le Potre et al 2002).

\section{Gambar.1 Hubungan antara Institusi dan} Tindakan

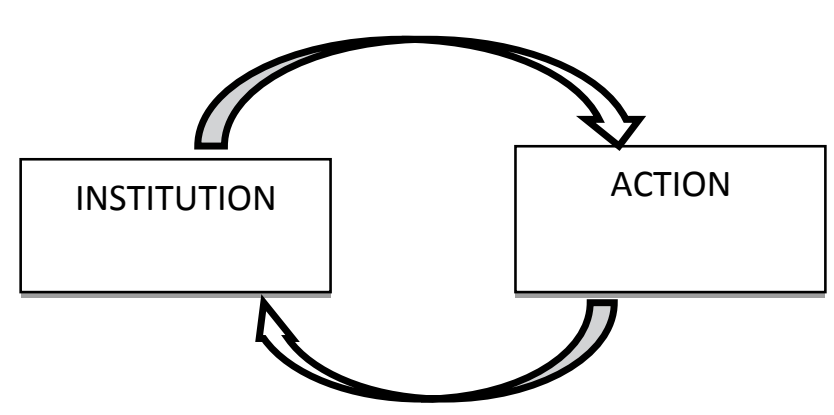

Sumber : Lawrence et al (2009)

Isomorpishm dapat terjadi karena pertimbangan populasi yang melihat bentuk performainstitusiyangnonoptimal.Selainitu, isomorpishm dapat terjadi karena pengambil keputusandidalaminstitusiyang belajarlebih lanjut mengenai respon agen dan kemudian menyesuaikannya kembali perilaku institusi (Dimaggio \& Powel 1983; Freeman, 1977). Tiga mekanisme InstitutionalIsomorpishm menurut Dimaggio dan Powel (1983). Coercive Isomorpishm merupakan dampak dari tekanan formal dan informal pada organisasi. Hal ini dimulai dari organisasi dengan organisasi lain di mana mereka bergantung. Selain itu, tekanan dari harapan budaya dalam masyarakat berdasarkan fungsi organisasi. Tekanan dapat dirasakan sebagai kekuatan, dan persuasi. Sebagai kekuatan yang menekan, Perubahan ini terjadi dari respon langsung mandat pemerintah seperti regulasi tentang pelayanan publik untuk mengadopsi teknologi. Sebagai persuasif bahwa negara yang telah terasionalisasi dan organisasi rasional besar lainnya memperluas dominasinya atas arena dari kehidupan sosial. Struktur organisasi untuk mencerminkan aturan yang dilembagakan dan sah dalam negara. Dampaknya adalah terjadinya homogenisasi organisasi dalam domain tertentu dan semakin terorganisir di sekitar penyesuaian ritual dengan lembaga yang lebih luas. (Dimaggio \& Powel 1983; Meyer et al, 1981).

Mimetic Isomorpishm adalahmekanisme perubahan berasal dari otoritas yang mendorong imitasi. Hal ini terjadi ketika teknologi organisasi yang kurang dipahami, ketika tujuan yang ambigu, atau ketika lingkungan menciptakan ketidakpastian simbolik, organisasi dapat memodelkan diri pada organisasi lain. Keuntungan perilaku mimetik dalam perekonomian cukup besar. Ketika organisasi mengalami masalah dengan penyebab ambigu maka isomorpishm ini dapat menghasilkan solusi yang layak dengan biaya sedikit (Dimaggio \& Powel 1983; Cyreth \& March, 1993).

Normative Isomorpishm adalah mekanisme perubahan yang berkaitan dengan profesionalisme. Menurut Larson (1979) profesionalisasi merupakan kondisi dan metode mereka bekerja dalam mengontrol produksi mereka. Hal ini bertujuan untuk membangun dasar kognitif dan legitimasi. Profesionalisme tunduk pada proses tekanan koersif dan mimetik. Profesi dapat juga merupakan hasil dari ciptaan negara. Terdapat dua aspek profesional yang merupakan sumber penting isomorphism. Pertama adalah pendidikan formal dan legitimasi di dasar kognitif yang dihasilkan oleh spesialis universitas. Yang kedua adalah pertumbuhan dan perluasan jaringan profesional yang mencakup organisasi dan seluruh yang model baru berdifusi dengan cepat. Satu mekanisme penting dalam mendorog normative isomorphism adalah penyaringan personil (Dimaggio \& Powel 1983; Larson, 1979). Menurut Dimaggio dan Powel (1983) penting dicatat bahwa setiap lembaga dapat diharapkan untuk meningkatkan efisiensi organisasi. 


\section{Adopsi Teknologi sebagai Proses Institusionalisasi}

Transformasi pelayanan publik dengan mengadopsiteknologi merupakan proses dari bentuk institusionalisasi. Institusionalisasi adalah proses sebuah ide dilegitimasi melalui aturan. Proses institusionalisasiinidigambarkan melalui aturan kebijakanyang menjadi acuan bagi seluruh jajaran pemerintahan. Kebijakan mengenai pengadopsian teknologi dalam pelayanan publik di Jakarta bermula dari keinginan Gubernur Basuki untuk menjadikan tata pemerintahan yang partisipatif dan transparan dalam rangka membangun kepercayaan masyarakat sehingga tujuan dari adopsi teknologi adalah membangunkepercayaan masyarakatmelalui transformasi pelayanan menjadi lebih transparan dan partisipatif. (Wawancara mendalam dengan informan o1 sebagai kepala UPT Jakarta smart city, 16 Desember 2016).

Berdasarkan tujuan tersebut, maka di bentuklah kebijakan melalui Pergub No. 280 Tahun 2014 untuk menginstuksikan membuat suatu institusi yang akan mengelola suatu konsep pembaharuan dari sistem tata pemerintah bernama Jakarta Smart City (wawancara dengan informan 02 sebagai Staff Jakarta Smart City, 15 November 2016). Menurut Informano1, Jakarta Smart City (JSC) diibaratkan sebagai "apapun makanannya, minumnya adalah JSC". Secara garis besar, JSC merupakan unit yang diharapkan seluruh banyak pihak dalam transformasi pelayanan publik melalui adopsi teknologi (Wawancara dengan informan or sebagai Kepala UPT Jakarta smart city, 16 Desember 2016). Jakarta Smart City memiliki 6 indikator kesuksesan yaitu Smart Governance, Smart People, Smart Living, Smart Mobility, Smart Economy, dan Smart Environment (Jakarta Smart City 2016). Hal ini menimbang bahwa dalam pengelolaan tata pemerintahan dalam indikator smart governance diperlukan suatu sinergi antara sumber daya dan teknologi informasi untuk membangun pemerintahan yang bersih, transparan dan berorientasi pada pelayanan publik. (Data Jakarta Smart City, Peraturan Gubernur No. 280 Tahun 2014, 15 November 2016).
Target yang dibayangkan oleh institusi adalah seluruh aparat pemerintah dapat menjadi digital technology officer dan berbagai pelayanan dapat ditingkatkan dengan memodernisasi setiap bisnis proses menjadi digital. Sistem ini juga sangat mudah karena pelayanan berbasis aplikasi dapat diakses oleh seluruh elemen yang menggunakan smartphone. Melalui target ini, Pihak Jakarta Smart City menilai bahwa proses pelayanan akan semakin mudah. (Wawancara dengan informan or sebagai Kepala UPT Jakarta smart city, 16 Desember 2016).Dalam pelayanan kelurahan, setiap laporan Qlue yang masuk akan langsung tersinkron dengan aplikasi CROP yang di unduh oleh Lurah. Laporan yang belum tertangani akan berwarna merah, laporan yang sedang dikerjakan berwarna kuning dan laporan yang telah selesai dikerjakan berwarna hijau (wawancara dengan informan 05 sebagai kodinator Qlue kelurahan, 6 Oktober 2016). Dalam Qlue RT-RW, pihak RT melaporkan perkembangan wilayah dalam upaya pertanggung-jawaban dan pelaksanaan tugas pokok meliputi kegiatan kerja bakti, kondisi sarana dan prasarana umum, kondisi sosial warga, data mobilitas penduduk, kegiatan pelayanan masyarakat melalui aplikasi Qlue (Pergub No. 903 Tahun 2016).

Mengantisipasi kenakalan aparat kelurahan, Teknologi Qlue memiliki mekanisme dalam menyaring laporan yang tidak jelas dari penangan kelurahan. Pertama, jika rating yang diberikan oleh user atau pengguna Qlue terhadap penanganan maka secara otomatis sistem akan memunculkan policeQlue yang bertugas untuk menindak laporan tersebut. Tahap kedua selanjutnya foto tersebut akan dinilai oleh Copas Qlue yang terdiri dari 15 anggota penilai selanjutnya jika dinyatakan buruk maka akan masuk dalam sistem door atau memerahkan kembali proses penganan. Dalam menanggapi mengenai tingkat kepuasan pengguna Qlue yang merunun sebenarnya itu bukan karena kinerja lurah yang semakin kecil melainkan karena warga masih salah mengira bahwa seluruh masalah harus diselesaikan oleh pemprov DKI 
Jakarta padahal permasalahan seperti jalan rusak juga harus dikordinasikan dengan SKPD terkait. Permasalahan lainnya adalah permasalahan berulang seperti kemacetan yang akan kembali lagi keesokan harinya. (Wawancara dengan informan o1 sebagai Kepala UPT Jakarta smart city, 16 Desember 2016).

Pengaruh aturan sangat terlihat dalam data PT Qlue menyebutkan bahwa sebanyak 268 kelurahan di DKI Jakarta termasuk Kepulauan Seribu telah menggunakan Qlue sebagai flatform dalam menjalankan tugas pelayanan publiknya. Hal ini menandakan bahwa 100 persen dari aparat kelurahan telah menggunakan adopsi teknologi ini. (wawancara mendalam dengan Informan 03 sebagai Humas PT Qlue, 11 Oktober 2016).Dalam Pergub No. 903 tahun 2016 menjelaskan mengenai perubahan fungsi dan wewenang organisasi publik dalam Pemprov DKI Jakarta sebagai dampak dari pengadopsian teknologi. Sistem ini juga mengatasi kelalaian yang terjadi pada level kelurahan.Menurut Informan 02 bahwa seluruh aparat pemprov DKI Jakarta berkewajiban untuk melaksanakan pergub tersebut terutama dalam melakukan program Cepat Respon Opini Publik (CROP) dalam rangka membantu visi dan misi yang dibawa oleh gubernur Basuki. Aparat pelayanan publik yang paling terdampak adalah Lurah dan RT-RW sebagai unit terkecil yang dekat dengan masyarakat (wawancara dengan informan o2 sebagai Staff Jakarta Smart City, 15 November 2016).

Kewajiban penggunaan dan penanganan Qlue ini telah terlegitimasi dalam Peraturan Gubernur No. 6 tahun 2016 mengenai perubahan atas Peraturan Gubernur No. 169 Tahun 2015 mengenai penanganan sarana dan prasarana umum tingkat lurah. Pergub tersebut berisi dalam penanganan permasalahan sarana dan prasarana berdasarkan laporan hasil Qlue pada tingkat kelurahan. Peraturan Gubernur No. 903 mengenai pemberian uang penyelenggaraan tugas dan fungsi rukun tetangga dan rukun warga yang berisi bahwa dalam pertanggung-jawaban terhadap uang insentif operasional maka RT-RW harus melaporkan perkembangan atau kejadian dan kondisi wilayahnya dalam bentuk upaya kinerja pelaksana tugas pokok melalui aplikasi Jakarta smart city. (data sekunder dari Jakarta Smart City). Menurut informan 04 sebagai Lurah Galur bahwa Qlue merupakan buatan pemerintahan provinsi DKI Jakarta yang tertuang dalam peraturan Gubernur Jakarta No. 903 tahun 2016 dalam pengaplikasian bagi aparat pemerintahan dan RT-RW. Dalam wawancara mendalam, ia mengutarakan bahwa jika tidak dapat mengatasi masalah lingkungan sekitar atau tidak dapat mengatasi laporan melalui Qlue maka aparat kelurahan akan dicopot atau di mutasi jabatannya. Pencopotan ini bahkan berjalan dalam hitungan bulan (wawacara dengan Informan 04 sebagai Lurah Galur, 24 September 2016).

Hal ini dikarenakan, Qlue ini merupakan aplikasi yang mampu menjadi trending topic dan memiliki aturan yang sangat ketat bagi aparat pemerintah khususnya di level kelurahan. Kinerja mengkordinir laporan warga dan mengkordinir laporan RT-RW melaui Qlue menjadi barometer kinerja seorang lurah. Ketika banyak laporan yang lama di tindak-lanjuti maka akan otomatis kelurahan tersebut menjadi peringkat paling bawah. Setiap kinerja ini di catat dalam kumpulan data di Jakarta Smart City dan kelurahan dengan peringkat terbawah harus siap-siap untuk diganti (wawancara dengan informan 02, 15 November 2016). Peraturan tersebut memacu lurah untuk memaksa aparat kelurahan untuk menggunakan Qlue bahkan setiap apel pagi, lurah galur selalu mengingatkan aparat kelurahan untuk menggunakan Qlue agar dapat membantu dalam respon cepat opini publik atau bahkan untuk menjadi pelapor permasalahan di lingkungan sekitarnya. Hal ini dikarenakan pergerakannya posisi aparat di pemerintahan DKI Jakarta sangat fluktuatif jadi bukan tidak mungkin jika aparat tidak sesuai dengan nilai-nilai yang diinginkan gubernur akan dicopot dari jabatannya (wawancara dengan informan 04, 24 September 2016). 
Tabel 1. Tiga Pilar Institusi

\begin{tabular}{|l|l|l|l|}
\hline & Regulatif & Normatif & Kognitif Kultural \\
\hline Dasar Kepatuhan & Kegunaan & Kewajiban Sosial & $\begin{array}{l}\text { Sudah biasa } \\
\text { pemahaman } \\
\text { bersama }\end{array}$ \\
\hline Dasar Tatanan & Regulatif Rules & Harapan mengikat & $\begin{array}{l}\text { Skema konstitutif } \\
\text { Mimetik }\end{array}$ \\
\hline Mekanisme & Paksaan & Normatif & Ortodoksi \\
\hline Logika & Instrumentalitas & Kewajaran & $\begin{array}{l}\text { Kepercayaan } \\
\text { bersama }\end{array}$ \\
\hline Indikator & $\begin{array}{l}\text { Aturan, Undang- } \\
\text { undang, Sanksi }\end{array}$ & $\begin{array}{l}\text { Sertifikat } \\
\text { Akreditasi }\end{array}$ & $\begin{array}{l}\text { Logika Aksi } \\
\text { bersama }\end{array}$ \\
\hline Perasaan & Takut bersalah & Malu/kehormatan & $\begin{array}{l}\text { Kepastian/ } \\
\text { kebingungan }\end{array}$ \\
\hline Basis Legitimasi & Sanksi Legal & $\begin{array}{l}\text { Dikelola secara } \\
\text { moral }\end{array}$ & $\begin{array}{l}\text { Dipahami diakui } \\
\text { secara kultural }\end{array}$ \\
\hline
\end{tabular}

Sumber: Meutia Rochman \& Rochman Ahwan (2014, 46)

Menurut pandangan Dimaggio \& Powel (1983), pemprov DKI Jakarta sebagai organisasi publik sangat berkaitan dengan institusionalisasi atau proses pelembagaan dalam upaya menjaga legitimasinya. Proses instititusionalisasi adalah bagaimana ide dapat disahkan menjadi sebuah aturan yang diikuti oleh seluruh populasi dalam organisasi tersebut. Institusionalisasi ini dapat menjelaskan dasaryang menjadi acuan dalam tindakan yang dilakukan aparat negara sebagai mekanisme yang dibentuk oleh struktur. Fenomena 100 persen kelurahan menggunakan Qlue sebagai bagian dari sistem CROP merupakan bentukan dari aturan atau regulasi yang di ciptakan oleh pemprov DKI Jakarta. Dalam pandangan ini, Scott (2001) dapat menjelaskan fenomena ini melalui 3 pilar.

Dasar kepatuhan Qlue adalah berdasarkan kegunaan. Qlue di gambarkan sebagai sesuatu yang dapat mempercepat bisnis proses menjadi digital. Dasar tatanan dari Adopsi Qlue adalah berdasarkan peraturan Gubernur Jakarta No 280 tahun 2014 dan peraturan Gubernur No. 930 tahun 2016. Dalam hal ini, Pergub tersebut menjadi petunjuk dalam melakukan tindakan pengadopsian Qlue ke dalam pemerintah. Aturan regulatif inilah yang menjaditatanan dalam bertindak. Seperti yang telah dikemukakan oleh data diatas bahwa lurah Galur menjalankan fungsinya dalam penanganan dan pengakomodiran laporan berdasarkan peraturan yang telah dibuat oleh Gubernur. Dalam aturan tersebut secara rinci menjelaskan tugas dan wewenangan pihak aparat negara sebagai pelaksana Qlue seperti apa yang seharusnya menjadi fungsi Jakarta Smart City dan bagaimana proses kerja kelurahaan dalam penanganan Qlue.

Jika membicarakan mengenai mekanisme maka akan terlihat jelas bahwa pengadopsian Qlue ini bermula dari paksaaan pemerintah provinsi kepada para jajaran aparat untuk membangun transparansi dalam pelayanan publik. Paksaan ini terlihat dari data yang menyebutkan bahwa seluruh kinerja lurah diukur melalui penanganan Qlue dan terdapat konsekuensi yang akan dihadapi jika adopsi Qlue ini tidak dijalankan dalam pemerintahan. Data diatas juga menyebutkan bahwa kinerja aparat kelurahan juga akan diukur melalui penanganan dan pengakomodiran Qlue. Hal ini menunjukan indikator utama yang digunakan peraturan gubernur, dan sanksi.

Basis legitimasi proses institiusionalisasi ini berdasarkan sanksi yang bersifat legal. Jika lurah tidak dapat menjalankan fungsinya dengan baik maka dengan segera akan dipecat atau dimutasikan. Dengan kondisi birokrasi 
yang sangat fluktuatif dan pejabat lokal bekerja berdasarkan kinerja. Sehingga sanksi legal ini cukup membuat lurah merasakan sedikit kecemasan dengan beberapa kalimat yang beliau lontarkan seperti mengharuskan kerja ekstra agar kinerja semakin baik dalam kondisi birokrasi yang sangat fluktuatif. Berdasarkan pemikiran Scott (2008) tersebut maka akan sangat terlihat bahwa institusionalisasi adopsi teknologi ini lebih condong mengarah pada pilar institusi regulatif.

Dalam kasus implementasi Qlue, aturan merupakan hal yang paling penting dalam pengadopsian teknologi ini. Aturan diharapkan akan mengurangi kompleksitas permasalahan dan menjadi instrumen untuk memproduksi keadilan melalui standarisasi. (Fountain, 2001). Setelah sebuah teknologi di adopsi dalam kebijakan maka Qlue bukan dinilai lagi dalam kapabilitas sebagai teknologi namun Qlue telah dilihat sebagai bagian dari mekanisme pemprov DKI Jakarta sebagai sebuah institusi. Institusi ini mengandung elemen regulasi yang kemudian mengarahkan sang aktor untuk bertindak.Oleh karena itu, kemudian penulis melihat bahwa Adopsi Teknologidalam tata pemerintahan ini dapat dilihat sebagai upaya proses institusionalisasi.

\section{Posisi PNS Menentukan Peran Lurah Sebagai Agensi}

Lurah sangat mengikuti aturan yang telah dibuat oleh institusi namun dalam pandangan agen, faktor penyebab hal itu adalah posisi PNS yang menentukan peran Lurah dalam pengimplementasian Qlue. Sebagai aparat negara yang sah atau disebut pegawai negeri sipil (PNS) pihak kelurahan harus mampu melaksanakan dengan baik penanganan dan mengkordinir laporan Qlue baik dari masyarakat maupun dari RT karena terikat pada aturan dan sanksi yang berlaku. Berdasarkan peraturan Gubenur No 251 tahun aparat kelurahan merupakan Pegawai Negeri Sipil (PNS) yang diangkat sesuai perjanjian yang memiliki tugas dan wewenang dalam menyelenggarakan urusan pemerintahan dari limpahan gubernur. Salah satu tugas lurah sebagai pimpinan tertinggi dalam struktur kelurahan adalah membina organisasi kemasyarakatan di wilayah kelurahan. Organisasi kemasyarakatan ini biasanya disebut RT (Data dari Jakarta Smart City).

Sebagai seorang abdi negara pihak kelurahan memiliki tugas untuk mengkordinasi dengan berbagai unsur terkait pelaksanaan tugas dan fungsi kelurahan. Salah satu tugas ini menekankan pada pentingnya menangani laporan yang dibuat oleh masyarakat serta mengkordinir Laporan Pertanggung-Jawaban (LPJ) RT melalui Qlue.Untuk saat ini, aplikasi Qlue ini menjadi barometer kinerja seorang lurah dengan berdasarkan rating yang dilihat dari cepatnya penanganan. Pergerakan rating tersebut sangat fluktuatif dalam hari yang sama. Bahkan dalam sehari dapat dua kali bergerak. (Wawancara dengan Informan 04, 24 September 2016). Dalam tataran hubungan antara pemerintah provinsi dan kelurahan, aplikasi ini sangat bergerak cepat. Aparat dipaksa melalui sistem rating untuk bekerja siang dan malam dan seolah-olah tidak ada hari libur. (wawancara dengan informan o6 sebagai Kepala Sarana dan prasarana Galur, 24 september 2016). Hal ini dikarenakan teknologi mampu membuat pimpinan langsung dapat memonitor perkembangan ini khususnya di Jakarta Smart city. Hubungan antara pimpinan provinsi hingga pimpinan kelurahan semakin dekat melalui Jakarta Smart City tanpa harus ke kecamatan terlebih dahulu(Wawancara dengan informan 05 sebagai Kordinator Qlue Galur, 12 Okotber 2016).Jakarta Smart City memiliki tim khusus yang mengawasi langsung di monitoring room sehingga jika ada rating kelurahan yang merah maka JSC akan secara langsung memberi peringatan dengan menelpon lurah dan memberi penjelasan lebih namun, juka tetap saja ratingnya merah maka akan disampaikan langsung pada Gubernur dan Gubernur memiliki kewenangan untuk memecatlangsungaparatyang tidak memiliki performa yabg baik (wawancara mendalam dengan informan o1 sebagai kepala UPT Jakarta smart city, 16 Desember 2016). 
Hal ini selaras dengan informan 04 sebagai lurah, beliau juga berfikir bahwa Qlue merupakan transformasi tata pemerintahan yang positif dan efisien. Secara pribadi beliau sangat mendukung penggunaan Qlue. Beliau merupakan lulusan S2 dari ilmu manajemen dan usianya zo tahunan sehingga kesempatan untuk jenjang karir berikutnya masih terbuka lebar. Dalam mengatasi kekurangan sistem makan JSC kemudian membuat mekanisme validasi pelaporan sehingga lurah pun mau tidak mau mengikuti aturan yang ada. Menurutnya jika ingin membuat laporan bohong maka user akan complain dan turunlah peringkat kelurahan(wawacara dengan Informan 04, 24 September 2016)

Data diatas menunjukan kuatnya peran institusi dalam hubungan dengan agen dan peran agen yang menyukseskan peran institusi. Penyebab pertama, posisi PNS dalam peraturan,lurah memiliki tugas limpahan langsung dari Gubernur dan wajib menaati dan berpedoman pada ketentuan peraturan perundangan jika tidak, maka akan di jatuhi hukuman disiplin yang telah dilegitimasi kedalam peraturan pemerintah No. 53 tahun 2010 dengan sanksi terberat adalah pemberhentian tidak hormat sebagai PNS. Menurut Hirsh (1997), Aturan institusi yang stabil digunakan sebagai pedoman oleh aparat di bawah dan disebarkan sebagai rutinitas dan program kinerja selaras dengan kerangka kerja yang lebih besar dan menciptakan ketaatan dari aparat negara. Penyebab kedua, Rentang otonomi antara Gubernur dan Lurah yang semakin dekat menguatkan cengkraman institusi dalam tindakan rasional aktor. Hal ini sejalan dengan pemikiran Scott (2008) pilar regulatif dalam institusi dapat bekerja untuk mengatasi, memperhitungkan, dan menjelaskan tindakan dan perilaku tingkat analisis individu. Penyebab ketiga, peran lurah sebagai agensi cenderung mengikuti rasionalitas untuk meniti karirnya. Menurut Fountain (2001) PNS secara rasional akan mengikuti sistem yang ada meskipun banyak hambatan yang tersedia karena sebagai agensi mereka fokus pada kesempatan untuk pembangunan profesional atau meniti karir.
Hal ini terlihat dalam pandangan lurah mengenai kesempatan meniti karir yang lebih tinggi dalam jabatan struktural.

\section{Penolakan Penggunaan LPJ melalui Qlue dari perspektif RT sebagai agensi}

Reaksi penolakan RT tercipta karena Hambatan yang disediakan oleh pemerintah, posisi RT sebagai lembaga masyarakat, dan perbedaan persepsi mengenai aturan. Rukun Tetangga atau yang biasa dikenal sebagai RT merupakan target langsung dari pelaporan pertanggungjawaban RT melalui Qlue dan juga sekaligus pelaksana dalam sistem pelaporan tersebut. Dalam upaya transformasi pelayanan publik melalui adopsi teknologi, ketua RT merupakan elemen terpenting karena melalui tindakan kolektifnya dapat menolak sistem tersebut. Ketua RT merupakan aparat negara bentukan warga yang disahkan oleh kelurahan dan menjadi bagian dalam kelurahan. Namun, RT bukanlah aparat negara yang disebut pegawai negeri sipil. Ketua RT kerap kali disebut pekerja sosial karena posisi ketua RT ini dipilih berdasarkan kesukarelaan dan kesadaran individu untuk maju dan bertugas untuk menjaga ketertiban lingkungan RT tanpa posisi sebagai pegawai negeri sipil. Posisi aparat semi formal inilah yang semakin memungkinkan tindakan kolektif ketua RT dapat mempengaruhi kebijkan yang ada.

Status dan kedudukan RT merupakan hal yang sangat mendasar untuk membahas mengenai tindakan penolakan yang dilakukan RT. Menurut Pergub No. 903 tahun 2016 bahwa RT merupakan lembaga yang dibentuk oleh masyarakat dan untuk masyarakat. Tujuan pendiriannya adalah untuk membantu kinerja lurah dalam urusan pemerintahan, pembangunan dan sosial masyarakat. (Data sekunder dari Jakarta Smart City). Dalam wawancara dengan informan o7 sebagai ketua RT, sebagian besar ketua RT di kelurahan galur masih belum menerima pergantian mekanisme laporan pertanggungjawaban menggunakan Qlue bahkan dalam salah satu RW, sebanyak 90 persen laporan pertanggungjawaban masih 
belum memenuhi kriteria jumlah yang harus di setor. Jumlah yang harus disetor adalah 9o laporan perbulan bahkan informan o9 jumlah laporannya kurang dari setengah jumlah yang seharusnya dilaporkan. Menurut beliau, salah satu alasannya adalah bahwa RT merupakan pekerja sosial sehingga status dan kedudukannya untuk mengayomi masyarakat yang bersifat tidak terikat sehingga RT berhak menentukan pilhannya dalam strategi pembangunan pelayanan publik dan sebagian besar RT di Galur menolak adanya pergantian sistem Qlue dan menginginkan kembali pada LPJ seperti biasa.((wawancara dengan informan o9, 12 Oktober 2016).

Menurut Pergub No. 903 Tahun 2016, Uang biaya operasional RT-RW bukan merupakan uang gaji atau honorium RTRW melainkan sebagai uang penunjang operasional tugas dan fungsi RT-RW yang harus di pertanggung-jawabkan dalam bentuk laporan. Namun menurut pihak RT bahwa sebagai pihak yang tidak terikat. Pemprov DKI Jakarta tidak seharusnya memaksa harus menggunakan teknologi dan memberikan biaya operasional karena itu menurunkan status RT. RT sekarang berlomba-lomba mendapatkan uang dan tidak terfikir sebagai penggerak masyarakat karena masyarakat pun tidak mau partisipasi di lingkungan dan menilai bahwa percuma jika RT di gaji namun masyarakat juga ikut berpartisipasi(Wawancara dengan Informan 10, 16 November 2016).

Terdapat hambatan-hambatan dalam pengimplementasian Qlue yang membuat pihak RT menilai negatif mengenai aturan pengadopsian Qlue. menurut informan 10, Qlue juga merupakan sumber konflik bagi kalangan aparat terkecil. Konflik itu baik pada sesama RT atau konflik antara RT dan masyarakat. Dalam suatu kasus antara informan o9 dan informan 10 mendapatkan fitnah dari warga yang tidak mengerti bahwa laporan pertanggung-jawaban berbeda dengan laporan masyarakat. Konflik paling banyak terjadi ketika pelaporan bangunan liar di tindak-lanjuit kelurahan. Imbas yang terjadi adalah pihak warga yang marah pada
RT yang dianggap sebagai oknum pelapor permasalahan tersebut. Kasus ini tidak hanya terjadi sekali saja namun berkalikali (wawancara terhadap informan o9 dan informan 10, 12 Okotber dan 16 November 2016) Hambatan lainnya adalah kurangnya SDM dalam struktur RT. Karakteristik pendidikan dan pekerjaan di kelurahan Galur juga tidak sering berkaitan dengan teknologi. Banyakdariwargagalur merupakan pedagang yang tidak menamatkan pendidikan sekolahnya sehingga ia pun susah untuk memilih sekertaris atau bendahara RT yang dapat mengoperasikan Qlue karena jika pendidikannya tinggi, terdapat kemungkinan ia bekerja dan ia tidak dapat bekerja optimal menjadi sekertaris RT. (wawancara dengan informan 09, 12 Oktober 2016). Hal ini tidak di atasi melaui aturan Gubernur sehingga permasalahan ini membuat RT semakin berfikir ulang mengenai penggunaan Qlue dalam laporan pertanggung-jawaban.

Menurut Meyer (2010), meskipun agen terintegrasi dalam struktur internal namun mereka tetap dapat bertindak independen dalam partisipasi mereka terhadap aturan institusi. Hal ini dapat terjadi karena agen merupakan aktor kolektif yang tidak terikat secara struktur terhadap institusi. Aktor kolektif ini memiliki posisi sebagai lembaga masyarakat dan tidak digolongkan menjadi pegawai negeri sipil sehingga,agen secara natural bertindak secara rasional untuk mendapatkan posisi yang menguntungkan dalam aturan institusi ini. Hal ini didukung oleh lingkungan institusional yang sangat kaya terdiri dari makna kultural yang kompleks dan struktur organizational. Setiap agen memiliki makna yang berbeda mengenai aturan institusi yang telah dibuat. Dalam kasus ini, makna mengenai biaya operasional RT diterjemahkan berbeda antara institusi dan agensi. Biaya operasional RT menurut agen termasuk ke dalam honorium. Dalam pandangan institusi, Biaya operasional RT merupakan biaya lembaga RT untuk melakukan kegiatan dan harus dipertanggung-jawabkan. Tindakan agen dengan menolak aturan institusi memperlihatkan bahwa hambatan yang 
disediakan institusiberhasil memberdayakan aktor untuk memilih tindakan yang harus dilakukan dalam menjaga kepentingan mereka sehingga mereka meminta dengan usaha sekecil-kecilnya namun menghasilkan posisi yang menguntungkan agen rasional. Hal ini diperkuat denganpower yang ada pada tindakan kolektif RT yang bertujuan mengubah tatanan institusi dalam aturan kelembagaan (Lawrence 2009). Tindakan ini dibangun untuk keuntungan mereka dengan melalui tindakan kolektif yang kuat dan berkepentingan (Dimaggio 1988, Powell \& Dimaggio 1991: Scott, 2008).

\section{Relasi Teknologi, Institusi, dan Agensi dalam Transformasi Pelayanan Publik di Jakarta}

Melalui analisis di atasrelasi teknologi, institusi dan agensi memiliki hubungan dua arah yang saling memiliki ketergantungan. Hubungan antara teknologi dan institusi terlihat dari kontrak dan aturan mengenai implementasi teknologi ini dan kemudian di sebut adopsi teknologi yang bersifat saling positif. Hubungan antara adopsi teknologi danagensi kelurahanjugasalingberhubungan dan bersifat postif. Hubungan antara adopsi teknologi dan agensi RT bersifat negatif yang akhirnya melahirkan isomorphisme yang merupakan faktor pendorong dari transformasi pelayanan publik. Hubungan ini akan di gambarkan melalui alur pemikiran seperti di bawah ini.

Gambar 2. Hubungan antara Teknologi, Institusi, dan Agensi dalam Transformasi Pelayanan Publik

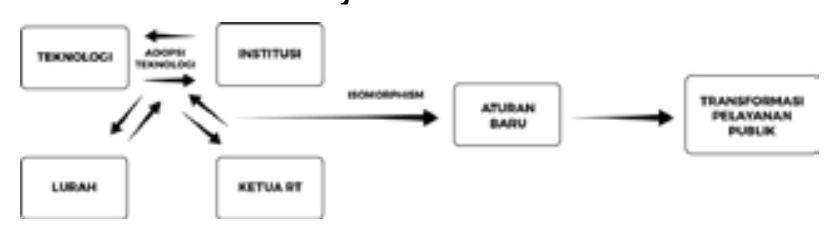

Sumber : Diolah oleh Penulis

Hubungan antara teknologi dan institusi dimulai ketika terdapat kontrak kerjasama antara pihak Jakarta Smart City sebagai perwakilan dari Pemprov DKI Jakarta dan PT Qlue performa Indonesia. Aplikasi Qlue ini mendukung program smart city dan membantu mewujudkan nilai-nilai yang ingin dicapai pemprov DKI Jakarta seperti nilai transparansi dan partisipasi publik. Sebaliknya, institusi juga mendukung keberadaan teknologi dengan membuat peraturan-peraturan agar setiap elemen dapat menggunakan teknologi ini dan khususnya bagi aparat agar dapat menjadi digital Technology Officer. Hubungan yang postitif ini kemudian melahirkan adopsi teknologi yang merupakan bentuk dari teknologi yang telah terinstitusionalisasi. Hubungan antara Adopsi teknologi dan kelurahan adalah positif dengan mengacu pada analisis subab sebelumnya mengenai posisi PNS dan peran kelurahan dalam Implementasi Qluebahwa dalam level institusi, aturan yang dibuat sangat ketat dengan sanksi yang tegas membuat Lurah mengikuti peraturan tersebut namun dalam sisi agensi, aturan tersebut juga sejalan dengan pemikiran dan tujuan utama Lurah sebagai birokrat karir. Menurut beliau sebagai pemangku wilayah, aparat harus cepat dalam respon keluhanpublik. selain itu, alasan terbesar adalah gubernur dengan singkat akan melakukan pencoptan jabatan dan pemutasian.

Hubungan antara kelurahan dan RT berjalan baik. Hal ini dikarenakan kelurahan dan RT saling membutuhkan. Di dalam sistem, kelurahan bertugas untuk membina lembaga kemasyarakatan sehingga mereka selalu melakukan pendekatan terhadap RT namun pihak RT juga melihat bahwa lurah sebagai validasi LPJ RT juga memiliki peran yang dominan jika LPJ tidak divalidasi maka biaya operasional RT tidak akan turun sehingga keduanya saling berhubungan baik bahkan sangat terlihat bersama dalam menanganni kasus pelaporan. Namun efek dari hubungan baik tersebut adalah RT tidak dapat mengakui keberatannya langsung melalui Lurah.

Hubungan antara Penolakan itulah yang menyebabkan hubungan antara adopsi teknologi dan pihak RT bersifat negatif. Terdapat gap antara struktur dan praktisnya. Agen mengadopsi kebijakan yang telah terimplementasi di lapangan dan meraka tidak memiliki kesesuaian dengan kebijakan 
pelaporan di hitung 3 kali sehari. Hubungan ini kemudian melahirkan Isomorphisme dalam institusi tersebut. Hal ini merupakan dampak dari tekanan penolakan pihak RT dan tekanan dari harapan budaya dalam masyarakat berdasarkan fungsi organisasi. Tekanan ini melahirkan perubahan sebagai respon dari regulasi tentang pelayanan publik untuk mengadopsi teknologi dan memaksa institusi membuat aturan baru yang akan memuat kepentingan mereka. (Dimaggio \& Powel 1983: Meyer et al, 1981). Oleh karena itu terbentuklah peraturan gubernur No. 2435 tahun 2016 yang memuat bahwa terdapat aturan pelaporan dan pemberian biaya operasional RT yang bersifat statis dan dinamis. Laporan kegiatan biasa RT akan mendapatkan uang sebesar $\mathrm{Rp}$ 400.000 dan $\mathrm{Rp} 575.000$ akan turun sesuai dengan jumlah laporan yang di upload melalui Qlue. Perubahan aturan ini menciptakan kepastian dalam institusi baru yang lebih stabil dan bertujuan untuk perubahan dalam pelayanan publik. Hal ini sejalan dengan pernyataan Yang (2003) bahwa neo-institutionalisme dapat membahas perubahan institusional yang termasuk dalam proses teknologi. Dalam level institusi, isomorphisme adalah mekanisme untuk bertahan atau survive yang kemudian dilakukan dengan cara difusi norma dan regulasi Yang 2003; Le Potre et al 2002) Dan peran agensi adalah RT sebagai agen adalah mengubah tatanan institusi dalam aturan kelembagaan melalui tindakannya (Lawrence et al, 2009).

\section{SIMPULAN}

Daripembahasandiatas, penulismenarik kesimpulan bahwa transformasi pelayanan publik tidak hanya terjadi akibat pengaruh teknologi yang diusung oleh pemerintah provinsi DKI Jakarta. Transformasi melalui teknologi dapat terjadi ketika teknologi dapat terinstitusionalisasi dengan baik melalui aturan namun, institusi juga harus dapat memperhitungkan hubungan antara agen dan lingkungan institusional. Hal ini dikarenakan para agen dapat melakukan pertimbangan atas kesempatan dan hambatan yang disediakan oleh institusi.
Hal ini menguatkan argumen penulis bahwa proses relasi antara teknologi, institusi dan agensi dapat mempengaruhi proses transformasi pelayanan publik.

Temuan dalam artikel ini dapat mengisi kekosongan pada pandangan sebelumnya mengenai transformasi pelayanan publik. selain itu, tulisan ini dapat membantu menjelaskan faktor yang mempengaruhi peran agen dalam tindakan yang berdampak pada institusi dalam tulisan Lawrence et al (2009). Pertama, kesadaran kolektif agen ditentukan oleh jabatan struktural yang diembannya. Jabatan yang memiliki sanksi formal yang tegas seperti pemecatan langsung cenderung membuat agen tidak memiliki keterampilan dan refleksivitas sebagai agen karena dalam perspektif agen sebagai birokrat karir, tujuan utamanya adalah meniti karir tersebut. Kedua, teknologi membantu institusi dalam mengantisipasi kecurangan yang dilakukan oleh aparat tanpa memandang individual semakin memperkecil perbedaan dampak agen dalam institusi. Ketiga, praktik yang dilakukan oleh agen semakin membuat aturan terlegitimasi dan mempengaruhi persepsi agen.

Artikel ini juga dapat mengisi pandangan Yang (2003). Sisi lain pembahasan ini tidak sepenuhnya memandang bahwa institusi sangat berkuasa atas agen. terdapat faktor penting lain selain dari institusi untuk menjelaskan bagaimana teknologi dapat diadopsi dan digunakan dalam pemerintahan. Pada kasus ini, tindakan agen yang tidak terikat secara kolektifitas mampu mempercepat institutional isomorphism dalam organisasi publik tersebut. Penyesuaian kembali perilaku institusi akibat tindakan kolektif agen dapat menjadi solusi dalam mengurangi terjadinya konflik antara proses institusionalisasi dan kepentingan agen. Hal ini memperlihatkan bahwa institusi yang diidentikan dengan stabilitas dan durabilitas mampu melakukan perubahan dengan begitu cepat sebagai mekanisme institusi untuk survive. Artikel ini melihat bahwa dalam transformasi pelayanan publik melalui teknologiterdapat pengaruh institusi yang kuat untuk menyebarkan teknologi dan agen untuk menyesuaikan aturan dalam tataran mikro. 


\section{UCAPAN TERIMA KASIH}

Alhamdulillah, Terimakasih saya ucapkan kepada mba Meuthia Ganie Rochman sebagai pembimbing saya yang telah banyak menginspirasi saya dalam menulis artikel ini. Terimakasih kepada ibu saya tercinta yang selalu mendorong saya hingga mampu melewati tahap ini. Terimakasih kepada my beloved Nauval Fauzi yang selalu ada dan membantu saya melewati tahap ini. Terimakasih kepada mba Diatyka dan mas Andi yang telah membimbing penulisan jurnal ini. Terimakasih kepada keluarga, Sahabat, dan teman-teman yang tidak dapat saya sebutkan satu-persatu yang telah mendukung saya dan membantu saya melewati tahap ini.

\section{DAFTAR PUSTAKA}

Albino et al. (2015). "Smart Cities: Definitions, Dimension, performance, and Initiatives". Journal of Urban Technology,1-21.

Bakici, et al. (2013). "A Smart City Initiative: the Case of Barcelona”. Journal of the Knowledge Economy, 4(2), 135-148.

Brewer, Brian. (2007). "Citizen or costumer? Complaints Handling in the Public Sector". Intenational review of administrative science. SAGE Publications.

Caillier, James Gerard. (2016). "Public Service Motivation and Decisions to Report Wrongdoing in U.S Federal Agencies: is This Relationship Mediatedby the Seriousness of the Wrongdoing". American Review of Public Administratation, SAGE Publications.

Dameri, Renata Paola etal. (2015). "Governing Smart Cities: An Empirical Analysis". Social Science Computer Review. SAGE Publications.

Dimaggio, Paul J et al. (1983). “The Iron Cage Revisited: Institutional Isomorphism And Collective Rationality in Organizational Fields”.
American Sociological Review. J STOR Publications.

Hirsch, P. M. (1997). "Sociology Without Social Structure: Neoinstitutional Theory Meets Brave New World". American Journal of Sociology. JSTOR Publications

Lawrence, T. B et al. (2009). "Institutional Work:ActorsandAgencyinInstitutional Studies of Organization”. Cambridge University Press. SAGE Publications.

Mahizhnan, Arun. (1999). Smart Cities: Singapore Case. Singapore: The Insititute of Policy Studies.

Mahler, Julianne et al. (2002). Learning To Govern Online Federal Agency Internet Use. USA: SAGE Publications.

Meijer et al. (2016). "Governing The Smart City: A Review Of The Literature On Smart Urban Governance”. International Review of Administrative Sciences.

Meyer, John W. (2010). "World Society, Institutional Theories, and Actor". Annual Review of Sociology. JSTOR Publications

Odendaal, Nancy. (2003). Information and Communication Technology and Local Governance: Understanding the Difference Between Cities in Developed and Emerging Economies. Computer, Environment, and Urban System. Pergamon Publicantion.

Scott, Richard W. (2008). "Approaching Adulthood: The Maturing of Institutional Theory". Theory and Society Vol 37. JSTOR Publications

Smith, Rodney. (2010). "The Role of Whistleblowing in Governing Well: Evidence from the Australian Public Sector". The American Review of Public Administration.

Styawan, Suci. (2013). "Penanganan Pengaduan (Complaint Handling) Dalam Pelayanan Publik (Studi Tentang Transparansi, Responsivitas, Dan Akuntabilitas Dalam Penanganan 
Pengaduan di Kantor Pertanahan Kota Surabaya II)". Jurnal Administrasi Negara.

Sumanjeet. (2006). "E-Governance": An Overview Indian Context. Indian Political Science Association. JSTOR Publications.

Utomo, Sad dian. (2008). "Penanganan Pengaduan Masyarakat Mengenai Pelayanan Publik. Bisnis \& Birokrasi”. Jurnal Ilmu Administrasi dan Organisasi.

Ganie-Rochman, Meuthia. (2014). Sosiologi Korupsi: Isu, Konsep, dan Perdebatan. Jakarta: Penerbit Universitas Indonesia

BPS DKI Jakarta. (2014). Data politik, Hukum, Pertahanan, dan Keamanan. Jakarta: Katalog BPS 1102002.202014

Wattimena, Lidya. (2012). Ahok Laskar Pelangi Transparan dan Profesional. Jakarta : Tabloid Refotmata edisi 152; 19

\section{Website}

Kementerian Dalam Negeri. 2009. 20 Persen Wilayah Jakarta Pemukiman Kumuh. Diakses Melaui http:// www.kemendagri.go.id/ news/2009/05/11/20-persen-wilayahjakarta-permukiman-kumuh pada 01 oktober 2016 pk. o6.oo

Kompas.com. 2016. Ini Tiga Kelurahan Terbaik dan Terburuk di Jakarta Versi Qlue. diakses melalui megapolitan .kompas. com/read/2016/o6/01/10142611/ ini. tiga.kelurahan .terbaik.dan.terburuk. di.jakarta.versi.Qlue 1o September 2016 pk 07.47 WIB

Pemerintah DKI Jakarta. 2016. Warga Aktif di Qlue Dapatkan Hadiah http:// www.jakarta.go.id/v2/news/2016/o1/ warga-aktif-di-Qlue-dapat-hadiah\#.VJP8yF97IU pada 21 September 2016 pk. $16.22 \backslash$

Pemerintahan Provinsi DKI Jakarta. 2015. Tingkat kemiskinan Di DKI Jakarta Maret 2015. Artikel online diakses melalui http://www.jakarta.go.id/v2/ news/2015/o9/tingkat-kemiskinandi-d ki - jakarta-maret-2015\# . WAeQbI997IU pada o1 oktober 2016 pk 05.00

Detik.com.2016.Prof.SuraryatiNilaiBirokrasi yang BurukJadi Sumber Penyakit Pungli. Diakses melalui http://news.detik. com/berita/d-3330373/prof-sunaryatinilai-birokrasi-yang-buruk-sumberpenyakit-pungli pada o1 Oktober 2016 pk 06.oo.

Liputan6.com. 2016. Meski Di tolak RT dan RW Aplikasi Qlue di Pakai 50o Ribu Warga Jakarta diakses melalui http:// citizen6.liputan6.com/read/2519834/ meski-ditolak-rtrw-aplikasi-Qluedipakai-50o-ribu-warga-jakarta pada o1 Oktober 2016 Pk 06.02.

Berita Satu.com. 2016. Laporan Pengaduan MasyarakatKeOmbudsmanMeningkat. Diakses melalui http://sp.beritasatu. com/home/laporan-pengaduanma syarakat - ke - o m bud s man meningkat/28444 pada o1 Oktober 2016 pk 08.03

OmBudsman Republik Indonesia. 2015. Laporan Tahunan 2015. Diakses melalui file:/ / C:/Users/ELY/Downloads / Laporan\%2oTahunan\%202015.pdf pada o1 Oktober 2016 Pk 09.0o

OmBudsman Republik Indonesia. 2015. Hasil Penelitian Kepatuhan Pemerintah Pusat Dan Pemerintah Daerah Terhadap Standar Pelayanan Publik Sesuai Uu No. 25 Tahun 2009 Tentang Pelayanan Publik. diakses melalui file:///C:/ Users/ELY/Downloads/Ringkasan\%20 Hasil\%2oPenelitian\%2oKepatuhan_ ORI_2015\%20(1).pdf pada o1 Oktober 2016 Pk 09.01

Undang-Undang No 25 Tahun 2009 diakses melalui http://www.imigrasi.go.id/ phocadownloadpap/UndangUndang/ nomor\%2025\%2otahun\%202009.pdf pada o1 Oktober 2016 pk 10. 
